\title{
ALEKSANDRA PINKAS
}

ORCID: 0000-0003-1413-0730

Uniwersytet Wrocławski

293159@uwr.edu.pl

\section{Sprawozdanie z Dolnośląsko-Saksońskiego Spotkania Administratywistów (Wrocław, 29-30 listopada 2019 roku)}

Dolnośląsko-Saksońskie Spotkanie Administratywistów (Sächsich-Niederschlesiche Konferenz für Verwaltungsexperten) to cykliczne wydarzenie wspólorganizowane przez Wydział Prawa, Administracji i Ekonomii Uniwersytetu Wrocławskiego. Druga w tym roku edycja tego wydarzenia odbyła się w dniach 29-30 listopada 2019 roku. Jego uczestnicy spotkali się w stolicy Dolnego Śląska, aby dyskutować o tym, na jakim etapie jest dziś administracja, dokąd zmierza, skąd chce czerpać impulsy do rozwoju.

Pierwszy dzień konferencji odbył się dzięki uprzejmości i wsparciu miasta Wrocławia we wrocławskim ratuszu, w sali obrad Rady Miejskiej. Uczestników spotkania przywitali: rektor Uniwersytetu Wrocławskiego prof. dr hab. Adam Jezierski; dziekan Wydziału Prawa, Administracji i Ekonomii prof. dr hab. Karol Kiczka; wicedyrektor Instytutu Nauk Administracyjnych dr hab. Piotr Lisowski, prof. nadzw. UWr; kierownik Zakładu Ustroju Administracji Publicznej Instytutu Nauk Administracyjnych dr hab. Jerzy Korczak, prof. nadzw. UWr; przewodniczący Rady Miejskiej Wrocławia mgr Jarosław Charłampowicz; oraz dyrektor Instytutu Rozwoju Terytorialnego, przedstawiciel Marszałka Województwa Dolnośląskiego dr Maciej Zathey. Kierownikiem organizacyjnym i merytorycznym konferencji była dr hab. Renata Kusiak-Winter, sekretarzem zaś - dr Justyna Mielczarek-Mikołajów z Zakładu Ustroju Administracji Publicznej.

Po uroczystym otwarciu konferencji nastąpiło podpisanie umowy o współpracy Uniwersytetu Wrocławskiego, Wydziału Prawa, Administracji i Ekonomii z Saksońską Szkołą Administracji Publicznej (Hochschule Meißen (FH) und For- 
tbildungszentrum), co sprzyja perspektywie dalszych spotkań koncentrujących się wokół szeroko rozumianej administracji z udziałem przedstawicieli obu ośrodków.

Tematem tegorocznej debaty była smart administration. Gdyby chcieć w jednym zdaniu oddać to, co wydarzyło się tego dnia, trzeba by powiedzieć tak: blisko dziesięć godzin rozmów, sześć godzin debat, kilkunastu referentów z Polski i Niemiec, ponad stu uczestników. Wniosek jest jeden — dyskusja nad kształtem administracji i jej przyszłością jest potrzebna. Steve Jobs, założyciel Apple Inc., pionier technologii na całym świecie, ale przede wszystkim człowiek ceniony za swoją wiedzę, którego życie determinowało przekonanie, że jest wart tyle, ile pozostawi po sobie, powiedział podczas swojego wystąpienia na Uniwersytecie w Stanford: „Prostota może być trudniejsza od komplikacji: trzeba się ciężko napracować nad wydobyciem czystej myśli, która pozwala na prostotę. Ale warto — bo kiedy już się to ma, można przenosić góry". Właśnie ta myśl przyświecała wszystkim uczestnikom w trakcie konferencji.

Pierwszy panel poświęcony został pojęciu smart administration w perspektywie teoretycznej i praktycznej. Panel otworzyło wystąpienie prof. dr Claudii Lubk, która skupiła się na ekonomicznym aspekcie smart administration. Podkreślone zostało, że administracja w koncepcji smart to wyzwanie długodystansowe, które początkowo może generować koszty, ale docelowo prowadzi do ich redukcji, a nawet zysków na nowych polach. Według poglądu prof. Lubk konieczna jest „ścisła symbioza" pomiędzy rozwojem administracji a inwestycjami w sektorze prywatnym, które wzajemnie na siebie oddziałują na zasadzie koła, zataczając krąg - począwszy od inicjatywy obywatelskiej, poprzez umiejętności obserwacji rynku, po sprawiedliwy model kontroli. Istotna jest świadomość potrzeby odpowiedzialności za model złożony z wzajemnych, nierozerwalnych relacji.

Następnie referat wygłosiła dr hab. Renata Kusiak-Winter, która skoncentrowała swoje rozważania w obszarze perspektywy nauk prawnych, podkreślając konieczność zwrócenia uwagi na relacje smart administration $\mathrm{z}$ różnymi gałęziami prawa. Konieczne jest zauważenie powiązań i wzajemnych oddziaływań związanych z hierarchiczną budową systemu prawnego (począwszy od prawa konstytucyjnego, prawa unijnego, przez kolejne gałęzie prawa, a w prawie administracyjnym - przenikanie się prawa ustrojowego, materialnego i procesowego). Digitalizacja administracji wymaga zmian w prawie, ale oparta ma być na platformach cyfrowych (prawo pozostające w sferze analogowej musi dogonić rzeczywistość, która jest już cyfrowa). Jednocześnie należy pamiętać, że proces digitalizacji musi uwzględniać prawa podstawowe jednostki, filary porządku prawnego zagwarantowane konstytucyjnie. Administracja powinna przejść wiele zmian nie tylko na szczeblu administracji centralnej, lecz także w samorządzie terytorialnym, gdyż te poziomy muszą wzajemnie się przenikać i kooperować. Przed nową administracją stoi zadanie nie tylko tworzenia możliwości elektronicznego załatwienia sprawy, lecz także wzrastającego w ten sposób poziomu partycypacji obywatelskiej. 
Profesor dr Isabelle Jänchen skupiła się na przyszłości smart miast i aspekcie ich finansowania. Punktem wyjścia jej wystąpienia było spostrzeżenie, że nie ma smart administration bez woli politycznej. Obecnie stanowiska co do tego, jak powinny wyglądać smart cities są bardzo zróżnicowane, a ich przyszłość uzależniona jest od wypracowania kompromisu ideowego. Miasto przyszłości według prof. Jänchen to miasto mobilne, zielone, funkcjonalne, ciche, przyjazne, którego siła bierze się ze słuchania potrzeb społeczeństwa i wdrażania odpowiadających im rozwiązań. Sukcesu nie da się osiągnąć tu i teraz, ponieważ jest to transformacja, a nie rewolucja. Dodatkowo idea ta musi mierzyć się z barierami finansowymi (ważny jest stabilny budżet). Trzeba brać pod uwagę, że zmiany nastąpią najszybciej za dziesięć lat. Pytanie — czy jesteśmy na nie gotowi.

Panel pierwszy zamknęło wystąpienie dr. Macieja Zatheya, dyrektora Instytutu Rozwoju Terytorialnego. Wyartykułował on apel, którego hasłem przewodnim była przestroga przed krótkowzrocznością w administracji. Miasta stoją obecnie przed nowym zadaniem, którym jest konieczność zapobieżenia globalnej katastrofie; walka z czystością powietrza, emisyjnością transportu, zrównoważonym zagospodarowaniem przestrzennym, brakiem dostępu do wody itp. Jeśli nie nastąpią zmiany dziś, tu i teraz, miasta staną się obszarem elitarnym, a należy przecież mieć na względzie sprawiedliwą redystrybucję dóbr i egalitarność. Dziś zmiany te postrzegane są tak, jakby mogły jedynie nastąpić w wyniku wielkich nakładów finansowych, a przyszłością jest przecież redukcja kosztów i społeczna dostępność.

Po krótkiej przerwie rozpoczął się panel drugi pod hasłem „Digitalna transformacja organizacji administracji publicznej”. Profesor dr Detlef Rätz podjął rozważania nad implementacją e-umiejętności do sektora publicznego. Przedstawił raport Komisji Europejskiej z 2019 roku dotyczący poziomu digitalizacji usług sektora publicznego w państwach UE, z którego wynika, że Polska znajduje się na pozycji dwudziestej czwartej, a Niemcy — dwudziestej piątej. Ta mało chlubna okoliczność powinna być pretekstem do wzmożonej dyskusji nad potrzebą zmian. Niemcy postawili sobie za cel online access law — by do 2020 roku wdrożyć blisko sześćset elektronicznych rozwiązań w administracji, z jasnym zastrzeżeniem, że ambicje te nie mogą zostać osiągnięte bez współpracy z branżą IT. Konieczne jest nabycie nowych umiejętności e-skills, by efektywnie korzystać z platform cyfrowych z korzyścią dla obu stron. Zdaniem referenta należy wykorzystać potencjał uniwersytecki, wyciągnąć wnioski z dotychczasowych postępów, unowocześnić obszary dobrze rokujące i wdrożyć nowoczesne rozwiązania.

Następnie głos zabrała dr Dominika Cendrowicz, której zdaniem źródła zmian w obszarze administracji należy upatrywać w zaleceniu Rady UE 22/05/2018 Key Competences for Lifelong Learning. De lege lata można spierać się nad mocą wiążącą takiego dokumentu unijnego, jednakże trudno odmówić tej regulacji siły sprawczej, obserwując globalne zmiany w administracji. Proces komputeryzacji rozpoczął się w Polsce już w 2002 roku, a jego głównymi założeniami są: rozwój e-usług, wprowadzanie platform cyfrowych w poszanowaniu praw obywa- 
telskich, tworzenie elektronicznych baz danych, edukacja społeczeństwa celem wzrostu społecznej potrzeby zmian czy zachęcanie do preferencji e-kontaktu. Dalszy rozwój smart administracji możliwy jest tylko z uwzględnienieniem kryterium społecznej świadomości, a więc nieprowadzący do wykluczenia. Przed nami zatem długa, pełna wyzwań droga.

Matthias Thum zainspirował nas bardzo odważną myślą o potrzebie odejścia od smart mainstream 3.0 na rzecz 4.0. Według referenta zmiany powinny być nakierowane na pełną efektywność pracownika, elastyczność, pełne wykorzystanie jego potencjału. Postulowany przez referenta model miałby polegać na spersonalizowanym podejściu do pracownika w taki sposób, by maksymalnie wykorzystać tak zwany kapitał ludzki. Dziś talent może być wyznacznikiem sukcesu, a nie tylko tak zwana twarda wiedza. Wszystko zaczyna się od poziomu strategii przedsiębiorstwa, poprzez rekrutację i tworzenie warunków pracy uwzględniających indywidualne cechy. Ta koncepcja o podłożu psychologicznym miałaby spowodować korzystne zmiany infrastrukturalne w skali makro.

Ideę administracji 4.0 kontynuował dr Maciej Błażewski, który zaznaczył, że wymaga ona zmian na poziomie technologii, ekonomii i prawa. Całość powinna opierać się o dwa połączone ze sobą elementy: edukację i informatyzację. Dzisaj obszary te rozwijają się osobno, a konieczna jest ich integracja oraz zwrócenie uwagi na nauki interdyscyplinarne, których intensywny rozwój obserwujemy na przestrzeni ostatnich kilku lat.

Magister Bartłomiej Jaworski, zamykając panel drugi, pokazał aspekt konfliktów oraz głosów opozycyjnych wobec smart administration. Dziś istotne zdaje się zwrócenie uwagi na umiejętności miękkie, jak na przykład umiejętności współpracy w grupie, ale często już na poziomie zdalnym, a więc współpraca w przestrzeni wirtualnej, poza miejscem pracy, co niestety napotyka problemy. Obecnie pracodawca może przechowywać dokumentację osobową i płacową elektronicznie; pojawia się zatem potrzeba zatrudnienia wykwalifikowanego pracownika, który będzie zarządzał bazą danych. Zmiany organizacyjne, które i tak za sprawą RODO nastąpiły już rok temu, wciąż wymagają doskonalenia, a przy tym udziału i akceptacji wszystkich, co może powodować konflikty. Istnieją różne drogi rozwiązywania sporów, a mnogość nowych zjawisk, szczególnie w aspekcie prawa pracy, będzie prowadziła do zrównywania się pozycji pracownika i pracodawcy, a także wymagała większej elastyczności od tego drugiego.

Panel trzeci otworzyło wystąpienie dotyczące demokracji kooperatywnej. Referat wygłosił prof. dr Manfred Schleer. Wskazał on, że wzrasta potrzeba zwrócenia uwagi na idee demokratyzacji w odniesieniu do wszystkich gałęzi prawa (rosnące na znaczeniu nie tylko w Polsce idee konstytucjonalizacji czy europeizacji prawa). Dziś wyróżniamy demokrację bezpośrednią i przedstawicielską, ale potrzebna jest również trzecia (nowa) — demokracja współdziałania. Kluczem jest połączenie podejścia liberalnego (rosnący wpływ obywatela na podejmowane działania), idei państwa republikańskiego oraz dyskursu opartego na komunikacji 
i konfrontowaniu różnych racji. Należy położyć nacisk na ambitne cele, nawet jeśli będą wymagały czasu, ale to właśnie dyskusja społeczna będzie motorem zmian.

Dr hab. Magdalena Tabernacka, prof. nadzw. UWr, podążając za ideą demokratyzacji, ale już w ujęciu globalnym, wskazała, że efektywność w administracji mierzona jest globalnymi relacjami społecznymi i ekonomicznymi. Prelegentka postawiła pytanie, jak daleka ma być współpraca międzynarodowa - czy rzeczywiście modelem docelowym jest jeden rząd reprezentowany przez wszystkie państwa. Powinniśmy brać pod uwagę, że tematy takie jak bezpieczeństwo, ekologia, pomoc humanitarna, ochrona zdrowia nie kończą się na granicach geograficznych, ale są naszym wspólnym interesem. Konieczne jest rządzenie państwem w oparciu o trzy determinanty: aktywność wewnątrzpaństwową, współdecydowanie i komunikację.

Z nieodwracalnym trendem digitalizacji wiąże się konieczność zapewnienia bezpieczeństwa w obszarach do tej pory nieznanych, a narażonych na tak zwane cyberataki. Tak swoją wypowiedź rozpoczął Daniel Andrae. Jego zdaniem technologia, oprócz tworzenia wirtualnej administracji, jest także zaporą przed niewłaściwym wykorzystaniem tej przestrzeni, przed przestępczością w sieci. Niestety prawo wciąż nie nadąża za lawinowym tempem rozwoju cyfryzacji, opierając się na ogólnych zasadach penalizacji zachowań niepożądanych. Niemcy już mogą pochwalić się rozwojem prawa w tym obszarze, a mianowicie poprzez uchwalenie Sächsisches E-Government-Gesetz. Być może jest to dobry impuls do zmian legislacyjnych w naszym kraju. Jako przykład została wskazana Estonia, w której wybory od 2005 roku odbywają się w ramach e-voting z użyciem kart z ID, podczas gdy w wielu krajach wyborcy głosujący elektronicznie wciąż są znikomym odsetkiem. Dlaczego? Być może wciąż w sferze administracji cyfrowej czujemy się mało bezpieczni. Jeśli tak, to jest to wyzwanie na najbliższe lata.

Kolejnym wystąpieniem był referat dotyczący partycypacji obywatelskiej w formie cyfrowej. Magister Marcin Stasz skupił się na obszarze smart government jako idei współdecydowania, która wciąż boryka się z niezrozumieniem i obawami, a przecież jej celem jest ,zbliżenie” obywatela do władzy. By urzeczywistnić proces digitalizacji i zwiększyć poczucie słuszności tej tendencji, należy wprowadzać zmiany, wykorzystując kryteria: prostoty, przejrzystości, jasności oraz intuicyjności. Uporządkowanie administracji i przygotowanie jej do trwałych i efektywnych zmian musi wiązać się z zażegnaniem chaosu legislacyjnego, co pozwoli zaoszczędzić czas zarówno samej administracji, jak również obywatelowi. Może to nastąpić wyłącznie w momencie, gdy zostanie wykorzystany cały potencjał naukowy i technologiczny.

Ostatnim wystąpieniem był referat ass. jur. Edgara Königa dotyczący powagi udziału młodych ludzi w sferze administracji oraz ich roli w jej reformowaniu. Według Königa podstawę prawną do partycypacji obywatelskiej dzieci i młodzieży wywodzić można z konwencji i innych międzynarodowych aktów, ale także z krajowej legislacji — podkreślają one rolę młodego człowieka w życiu publicz- 
nym, potrzebę wysłuchania jego głosu (dobrym przykładem jest chociażby Greta Thunberg, szesnastoletnia szwedzka aktywistka w dziedzinie przeciwdziałania zmianom klimatycznym). Aktywność młodych ludzi nie musi wyrażać się jedynie w sposób zagwarantowany prawnie, ale także poprzez ich głos na arenie samorządowej. Można więc zaryzykować tezę, że potencjał młodych ludzi mógłby „odmłodzić” administrację.

Spotkanie administratywistów nie zakończyło się w sali obrad, gdyż w kuluarach cały czas trwały żarliwe dyskusje, którym sprzyjała okoliczność, że była to niecodzienna okazja do wymiany poglądów na poziomie międzynarodowym. Merytoryczną część spotkania zakończyliśmy wizytą w muzeum Centrum Historii Zajezdnia, gdzie uczestnicy spotkania wysłuchali krótkiej lekcji naszej historii, dotyczącej najbardziej przełomowych wydarzeń w latach 1945-2016, której znajomość pozwala lepiej budować (smart) przyszłość, wykorzystując doświadczenia z przeszłości.

Drugi dzień konferencji naukowej koncentrował się wokół tematyki smart city i skierowany był w szczególności do studentów i doktorantów Zakładu Ustroju Administracji Publicznej - jak zostało wyartykułowane pierwszego dnia, to właśnie młodość jest kompasem administracji. Pierwszego dnia to pracownicy naukowi byli aktywnymi uczestnikami, którzy wygłaszali swoje referaty, a studenci występowali w roli słuchaczy, którzy zabierali głos jedynie w dyskusji popanelowej. Drugiego dnia sytuacja była odwrotna.

Opiekunem merytorycznym całego wydarzenia była dr hab. Renata Kusiak-Winter. Wsparcia organizacyjnego udzielili członkowie interdyscyplinarnego Studenckiego Koła Rozwoju Administracji ISKRA. Całość poprzedziło wystąpienie studentów czwartego roku studiów stacjonarnych prawa na Wydziale Prawa, Administracji i Ekonomii, uczestniczących w zajęciach z przedmiotu Standards in Public Administration in Poland and Germany. Studenci dokonali merytorycznego wprowadzenia do tej tematyki poprzez analizę samego pojęcia, różnych jego aspektów, obszarów podlegających regulacji smart; przedstawiono także głosy krytyczne. Warsztaty, jak cała konferencja, miały na celu połączenie teorii z praktyką.

Część praktyczna warsztatów polegała na rozwiązywaniu kazusów w grupach złożonych zarówno ze studentów i doktorantów z WPAiE, jak również studentów z Niemiec. Dotyczyły one przykładów miast, które próbowały być smart, lecz nie zawsze efekt końcowy był taki jak zamierzony. Studenci analizowali teksty napisane w języku angielskim, a następnie prezentowali odpowiedzi na zadane pytania. Wypowiedzi uczestników warsztatów były odzwierciedleniem wielu różnic w instytucjach prawnych funkcjonujących w Polsce oraz Niemczech.

Jednym z analizowanych przykładów był kazus postcolonial smart city dotyczący Indii. Właśnie tam zdecydowano się przeprowadzić konkurs na sto najlepiej rokujących inwestycyjnie miast. Na rzecz nich miał zostać rozdysponowany budżet wartości jedenastu milionów funtów, które to wsparcie miasta miały przeznaczyć na rozwój w kierunku smart. Całej idei, mimo pierwotnie wielkiego 
rozmachu, zabrakło jednak precyzyjnych kryteriów i dostosowania rozwiązań do poziomu społeczeństwa. Mimo dobrej współpracy administracji z sektorem IT nie udało się zrealizować marzenia o smart city, gdyż priorytety tamtejszej ludności były zupełnie inne. Jest to zatem jeden z kontrargumentów w dyskusji o idei smart, gdyż istnieje ryzyko wzrostu wykluczenia społecznego przy zbyt radykalnych zmianach. Należy zawrócić uwagę, że obecnie to deficyt budżetowy i bezrobocie są największymi hamulcami zmian — stąd potrzeba transformowania administracji w odpowiedzialny, racjonalny sposób.

Reasumując, smart według słowników Uniwersytetu Cambridge i Uniwersytetu Oxford oznacza „bycie inteligentnym, inteligentną metodę”. Idea smart administration jest właśnie taka. Celem zmian w administracji jest dążenie do spełniania oczekiwań społeczeństwa i nieustanne nadążanie za tempem zmieniającej się rzeczywistości z wykorzystaniem potencjału cyfrowego. Wyzwanie to wiąże się z klasycznym problemem powiązania prawa z dynamicznie zmieniającymi się potrzebami ludzi. Słowem kluczowym, postulowanym zgodnie przez prelegentów, jest kooperacja, a więc współpraca społeczeństwa z państwem, począwszy od wzrostu roli samej jednostki. Jest to także cel przyszłego spotkania administratywistów, by pogłębiać dialog międzyuniwersytecki, poznawać doświadczenia innych państw i udoskonalać prawo. 